(C) Dr W. Junk Publishers, Dordrecht - Printed in the Netherlands

\title{
Industrial tailings in Lake Traunsee (Salzkammergut, Austria)
}

\author{
Jens Müller ${ }^{1}$, Jürgen Schneider ${ }^{2} \&$ Michael Sturm ${ }^{3}$ \\ 'Lehrstuhl für Geologie, Technische Universität München, Lichtenbergstraße 4, D-8046 Garching, FRG \\ ${ }^{2}$ Institut für Geologie und Dynamik der Lithosphäre, Goldschmidtstraße 3, D-3400 Göttingen, FRG \\ ${ }^{3}$ EAWAG-ETH Zürich, Überlandstraße 133, CH-8600 Dübendorf, Switzerland
}

Keywords: lake sediments, turbidites, tailings, geochemistry, environmental hazards

\begin{abstract}
Tailings from salt work and a soda work have been pumped into the southern part of Traunsee (bay of Ebensee) for more than 50 years. Solid wastes have accumulated to form a pile $>40 \mathrm{~m}$ high with a total volume of $>3 \times 10^{6} \mathrm{~m}^{3}$. The sandy silty mud consists of calcite and other phases of $\mathrm{CaCO}_{3}$, brucite, $\mathrm{CaO}$ resp. $\mathrm{Ca}(\mathrm{OH})_{2}$ and gypsum. The chemical environment of the mud is characterized by extreme alkaline pore water $\left(\mathrm{pH}>10\right.$ up to 12.5; total amount of pore water: $\left.3 \times 10^{6} \mathrm{t}\right)$ and highly negative Eh-values. These values result from the pumped tailings and from postdepositional chemical processes such as dissolution resp. reaction of $\mathrm{CaO}$, brucite and gypsum and precipitation of $\mathrm{CaCO}_{3}$.

The high water content of the mud and the steep slopes $\left(>15^{\circ}\right)$ are responsible for frequent debris flows near the waste inlet, and occasional turbidity currents flow down to the distal basin floor. One particular current may transport up to $4 \times 10^{5} \mathrm{~m}^{3}$ of alkaline mud as far as $6 \mathrm{~km}$ from the inlet into the profundal basin plain, intercalating with natural lake sediments. Sedimentation rates in the northern part of Traunsee within the last decades are isotopically measured as $0.4-0.5 \mathrm{~cm} / \mathrm{a}$. In the central basin the sedimentation rates within the last 50 years are in the range of $2-3 \mathrm{~cm} / \mathrm{a}$. Up to $75 \%$ of the profundal sediments consist of industrial tailings and turbidites. Thus, within a substantial portion of the profundal zone (about $15 \%$ ) the benthic fauna and the chemical environment of the sediments are influenced by the alkaline tailings.
\end{abstract}

\section{Introduction}

Salt mining has a long tradition in the Salzkammergut area reaching back into prehistoric time. Mining and refinement techniques have changed in the course of times leading to the foundation of salt works in the year 1607 in Ebensee at the southernmost end of Traunsee. Availability of primary resources such as salt and carbonate initiated the establishment of soda works, which started production in 1885 .

Solid and dissolved wastes caused by the production of salt and of soda were first dumped into the river Traun or deposited on the southern shores of Traunsee. The disposal system was changed, however, when reduced fish catches and the build-up of a chemocline in Traunsee were observed. The pres- ent system, which has been in use for more than 50 years, consists of a sewer pipe where the combined wastes of the soda and the salt works are pumped into the lake after being diluted with lake water (Fig. 1). The dumping site is situated in the bay of Ebensee adjacent to the delta of the river Traun.

Presently solid wastes when leaving the works consist primarily of gypsum $\left(\mathrm{CaSO}_{4} \times 2 \mathrm{H}_{2} \mathrm{O}\right)$, brucite $\left(\mathrm{Mg}(\mathrm{OH})_{2}\right)$, calcite $\left(\mathrm{CaCO}_{3}\right)$ and of $\mathrm{CaO}$ resp. $\mathrm{Ca}(\mathrm{OH})_{2}$ (Fig. 1). Disposal rates are regulated by government authorities. They allow a total of $140000 \mathrm{t}$ of solid waste per year. This amount greatly exceeds the annual suspended and bedload from the river Traun of ca. $80000 \mathrm{t}$ (Müller, Sossau $\&$ Zeh, 1983). The Traun is the major natural source of allochthonous sediment for the Traunsee. Actual output of wastes ranged generally between 60000 


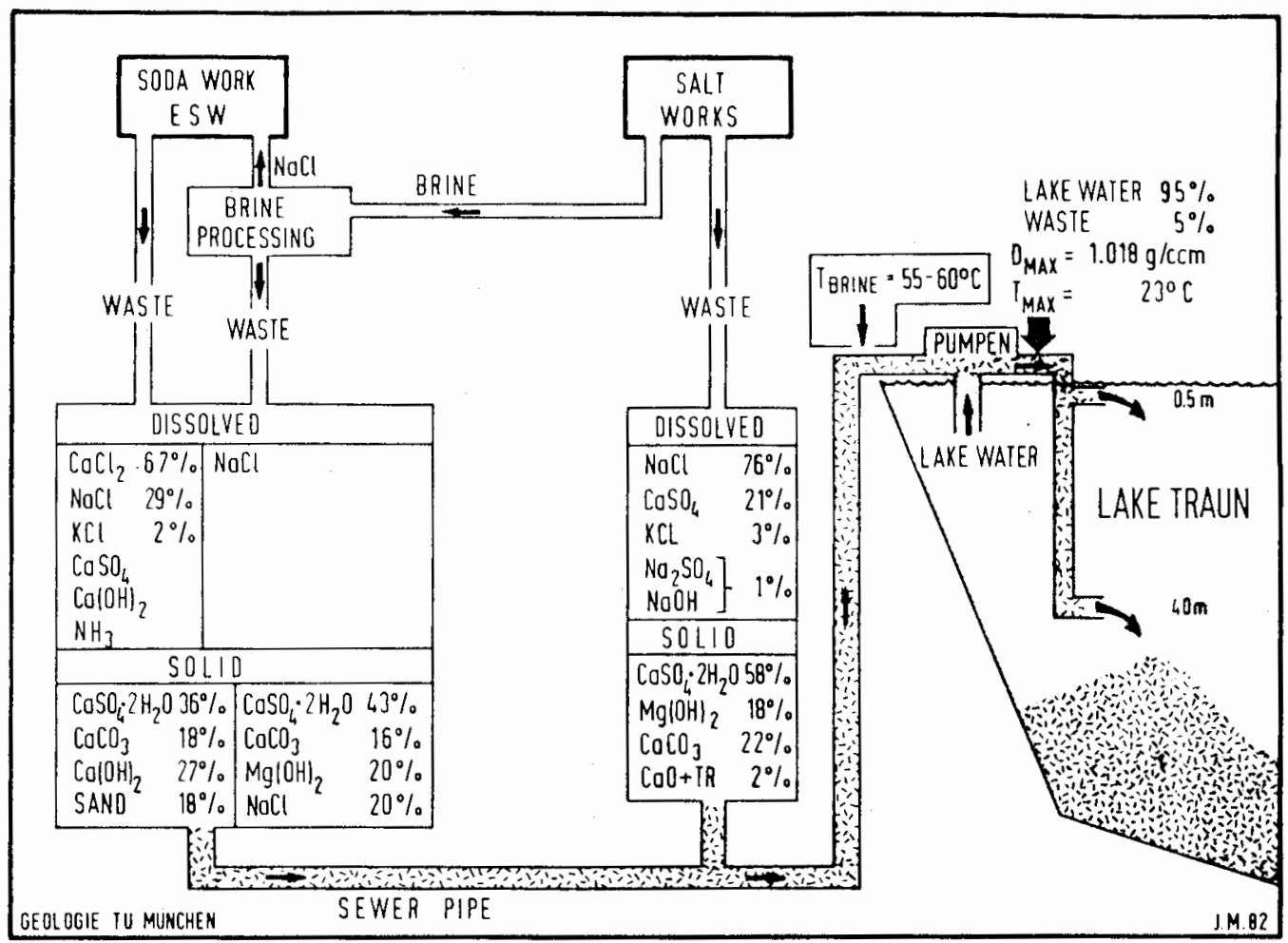

Fig. l. Schematic diagram showing the composition and the mode of dumping of the dissolved and solid tailings deriving from soda works and salt works in Ebensee. Data from the two factories (Sept. 1983). TR - clay residue. (Modified after Müller \& Schneider, 1984).

and $70000 \mathrm{t} / \mathrm{a}$ according to statements by the respective industries, but reached more than $90000 \mathrm{t} / \mathrm{a}$ during periods of $\mathrm{NH}_{3}$ production in the past. Disposal of dissolved wastes and its effects on the hydrography and chemistry of Traunsee are not treated within this report. They were discussed in detail by Pechlaner \& Sossau (1982).

\section{Accumulation and distribution of tailings in Lake Traun}

When entering the lake after dilution with lake water some of the components of the tailings dissolve on their way to the lake bottom. Thus, mineralogical and chemical analyses of core material taken in the bay of Ebensee showed pronounced differences in composition when compared with the material at source.

Tailings as accumulating on the lake floor consist primarily of calcite $(60-80 \%)$ and other phases of
$\mathrm{CaCO}_{3}$ (aragonite, vaterite) while gypsum and brucite are minor components which can only be detected within the uppermost sediments $(<0.5 \mathrm{~m})$. Reaction resp. dissolution continues under burial as is indicated by interstitial water analyses and increased $\mathrm{pH}$, ranging from 10 to 12.5 . Alkaline pore waters trapped within the tailings are due to the dissolution of $\mathrm{Mg}(\mathrm{OH})_{2}$ and of $\mathrm{CaO}$ resp. $\mathrm{Ca}(\mathrm{OH})_{2}$ which constitute the crucial components of the industrial waste.

The abundance of calcite within the tailings is partly the result of dissolution of other compounds. However, substantial amounts of calcite are precipitated in the lake water below the inlets and on the lake floor. Precipitation is favoured by the alkaline $\mathrm{pH}$-values leading to shifts in the carbonate system and to the dominance of $\mathrm{CO}_{3}^{-}$as the sole carbonate ion species. $\mathrm{Ca}^{++}$is present in the lake water; additional supplies come from the dissolution of gypsum and of $\mathrm{Ca}(\mathrm{OH})_{2}$. Sampling of suspended solids in the bay of Ebensee thus 
showed the presence of abundant 'autochthonous' calcite crystals. Calculations based on comparisons of actual output of calcite with the amount present in the bay of Ebensee indicate that about half of the calcite is of autochthonous origin and thus due to the alkalinity of the tailings.

Within the past 50 years $3.1 \times 10^{6} \mathrm{~m}^{3}$ of alkaline tailings have accumulated in the bay of Ebensee forming a $>40 \mathrm{~m}$ high pile (Fig. 2). Water content averages $60 \%$ which gives a total of $>3 \times 10^{6} t$ of

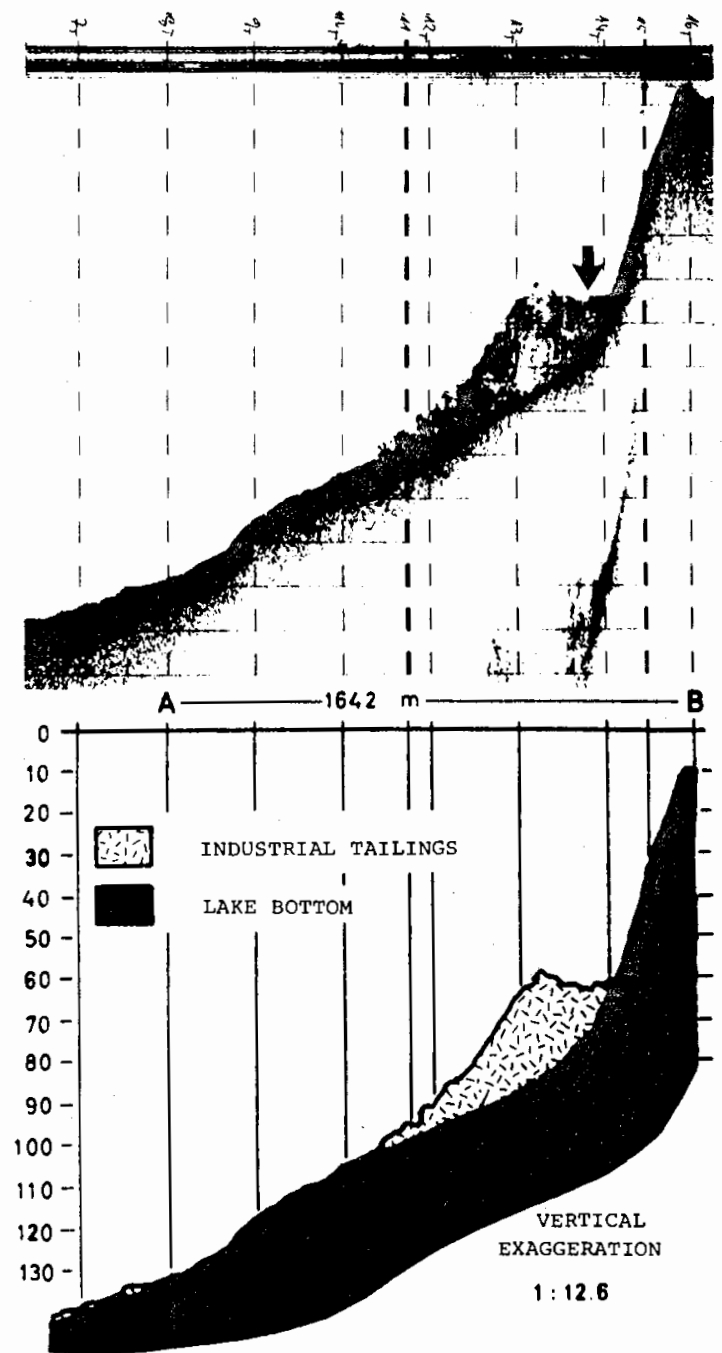

Fig. 2. Accumulation of tailings in the bay of Ebensee. Upper section: original $3.5 \mathrm{KHz}$ record, profile runs $\mathrm{NE}$ (point $\mathrm{A}$ ) to SW (point B). Arrow points to fault caused by slumping. Lower section: schematic graph illustrating natural lake bottom topography and superimposed industrial tailings. Depth scale in meters. (Modified after Müller \& Schneider, 1984). alkaline pore water trapped within the tailings.

Surface morphology, internal structures and distribution patterns document the instability of the deposits. The slope angle of the tailings ranged from $>15^{\circ}$ at the top to $>5^{\circ}$ at the foot of the accumulation. This is sufficient for the initiation of creeping, slumping and turbidity flows downslope into distal portions of the lake basin.

Triggering of these mass movements can be accomplished in several ways: oversteepening of siopes, earthquakes, sudden release of pore waters due to overburden or compaction, erosion of tailings by turbidity currents from the Traun delta, undercurrents during floods of the river Traun or slumping in the area of the adjacent delta foreset can cause the release of turbidity currents (Fig. 3).

Cores from the central basin of Traunsee showed numerous turbidites (up to $25 \mathrm{~cm}$ thickness) consisting of tailings material intercalated with normal sediments and turbidites derived from the river Traun.

These turbidites have been deposited up to $6 \mathrm{~km}$ away from the inlet in the bay of Ebensee and
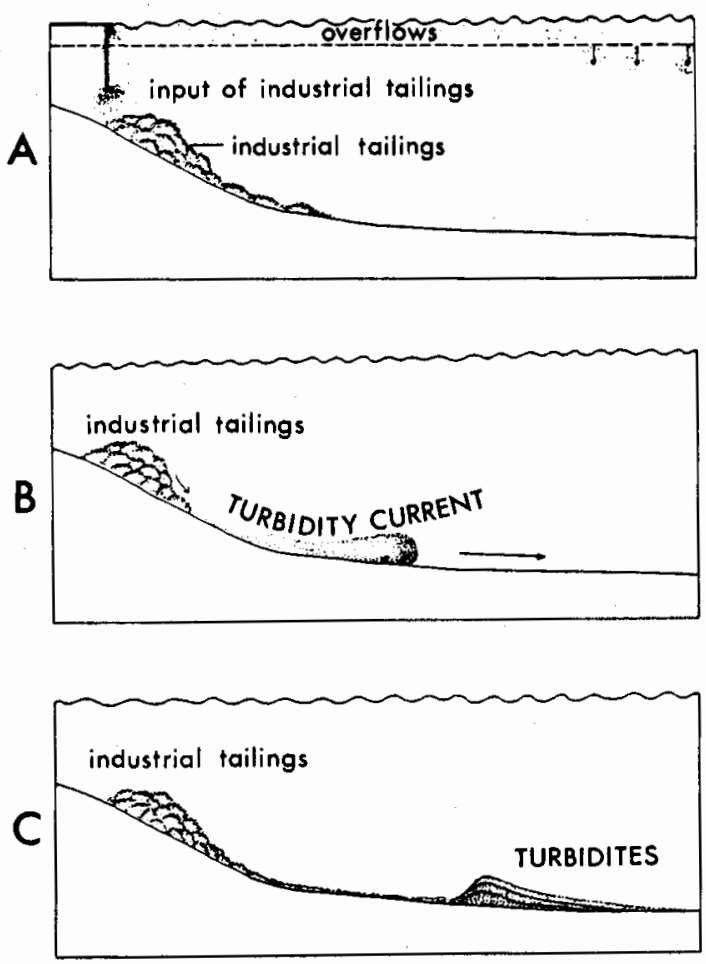

Fig. 3. Generalized diagram of turbidity current transport of tailings. (Modified after Müller \& Schneider, 1984). 
spread over large portions of the central basin. Presently $15 \%$ of the lake floor are influenced by the tailings (Fig. 4). In one case, a single turbidite transported $4 \times 10^{5} \mathrm{~m}^{3}$ into the central basin. Locally, these turbidites contribute $75 \%$ of sediments deposited in this area within the past 50 years, increasing the sedimentation rate by a factor of $>5$.

\section{Hazards}

Sediment transport by turbidity currents is a natural phenomenon. However, these specific tailings turbidites represent a special problem due to their alkaline pore water. $\mathrm{pH}$-measurements in cores containing tailings turbidites showed values ranging from 8 to 10 , while those of normal sediments are usually $<8$ (Fig. 5).

Several surveys and investigations (i.e. Hamann, 1954; Löffler, 1983) have shown that the benthic fauna is influenced by the tailings. Ostracods for example are missing in those areas where tailings have accumulated. The consequences for the ecosystem have yet to be studied.

Total slumping of the tailings would cover the profundal area in a thickness of $>1 \mathrm{~m}$. Even when covered later on by natural sediments, it can be expected that benthic life will be disturbed for substantial time periods by upward diffusion of alkaline pore waters.

The impact of tailings on the natural sedimentation processes and on the natural sedimentary environment remains to be investigated in the future. The observed increases in electrolyte content of the lake water (Pechlaner \& Sossau, 1982) can lead to enhanced flocculation of allochthonous sediment particles causing a rapid settling to the lake floor. Rapid rates of accumulation would therefore influence rates and modes of organic decay especially in the southern part of Traunsee. Another aspect concerns the dissolution of silicates (quartz, opal, feldspars and clay minerals) by alkaline pore waters leading to a mobilization of otherwise fixed or adsorbed heavy metals. The largest part of the tailings is accumulating on the unstable foreset slopes of the Traun delta with slope angles ranging from $20^{\circ}-30^{\circ}$. Possibilities have thus to be considered where slumping of tailings initiates mass slides in the delta area. Under these circumstances one has to expect damage in the shore areas similar to those

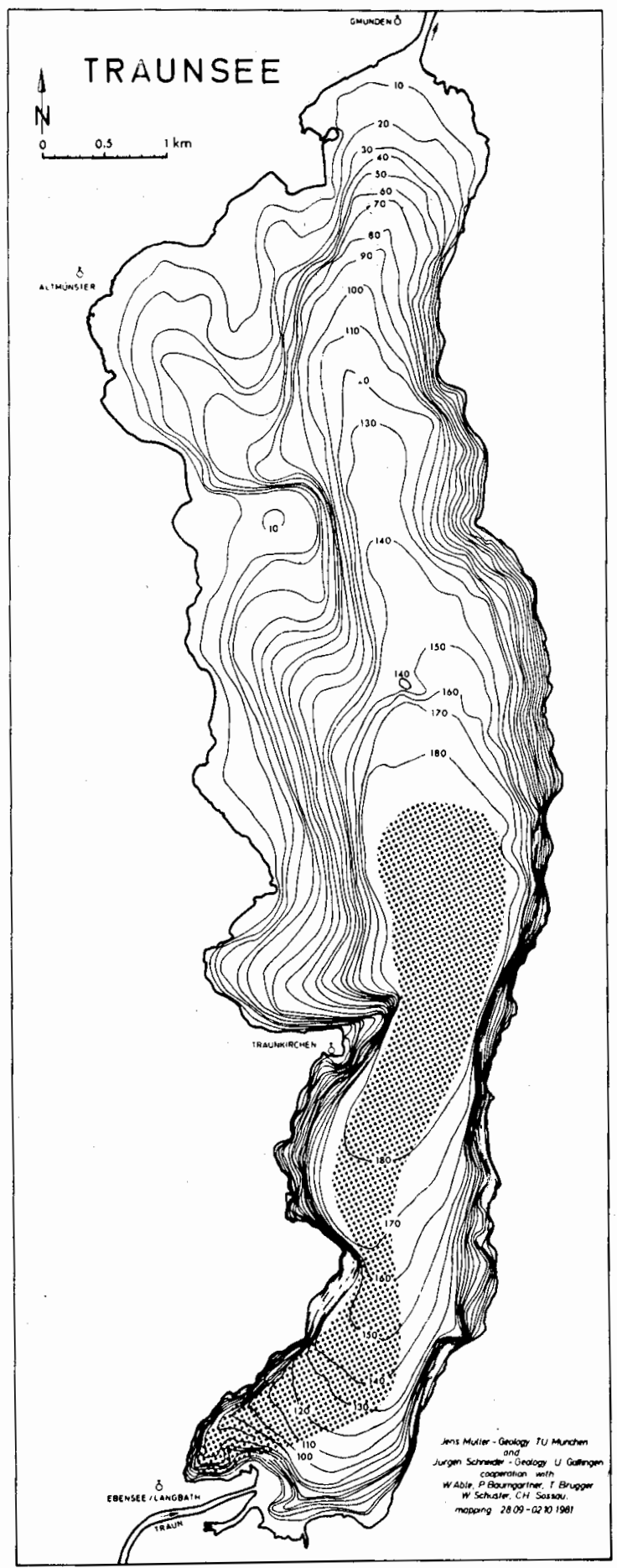

Fig. 4. Bathymetric map of Traunsee showing the distribution of tailings (shaded area) on the lake bottom. (Modified after Müller \& Schneider, 1984). 


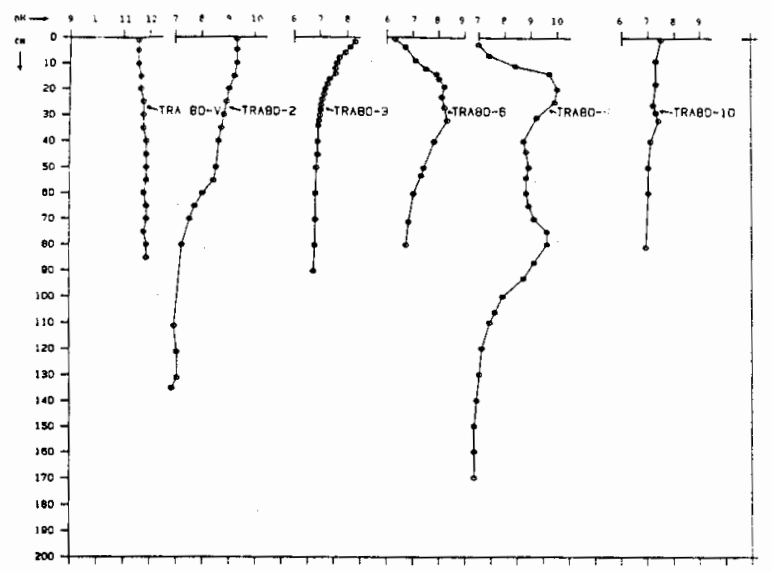

Fig. 5. pH-profiles versus core depth of different cores from Traunsee. $\mathrm{pH}$-values $>8$ document industrial tailings turbidities (after Sturm \& Müller, 1984).

described by Kelts (1978) in Swiss lakes or by Gennesseaux, Mauffret \& Pautot (1980) on the Mediterranean coast. In the latter case artificial sediments accumulated on delta deposits slumped into the sea causing a turbidity flow with speeds exceeding $40 \mathrm{~km} / \mathrm{h}$ destroying submarine cables at a distance of $100 \mathrm{~km}$ from its starting point. At the same time waves in excess of several meters flooded the coast.

\section{Acknowledgements}

The investigations were supported by a grant of the 'Amt der Oberösterreichischen Landesregierung' (AZ: Bau 2-12106/18-1980/Wei/St.).

\section{References}

Gennesseaux, M., A. Mauffet \& G. Pautot, 1980. Les glissements sous-marins de la pente continentale niçoise et la rupture de cables en mer Ligure (Mediterranće occidentale). C. r. Acad. Sci. Paris 290: 959-962.

Hamann, H., 1954. Beiträge zur Biologie und Ermittlungen zu den Fischereiverhältnissen des Traunsees (1952-53). Biol. Stat. Fischereiwesen, Linz, 246 pp.

Kelts, K., 1978. Gcological and sedimentary evolution of Lakes Zürich and Zug, Switzerland. Dissertation ETH Zürich, $242 \mathrm{pp}$.

Löffler, H., 1983. Changes of the benthic fauna of the profundal zone of Traunsee (Austria) due to salt mining activities. Hydrobiologia 103: 135-139.

Müller, J. \& J. Schneider, 1984. Die Industrieschlammablagerungen in der Bucht von Ebensee und im Profundal des Traunsees (Oberösterreich). Limnologische Untersuchung Traunsee-Traun Amt, O. Ö. Landesregierung Bericht Nr. 12a: $100 \mathrm{pp}$.

Müller, I., C. Sossau \& U. Zeh, 1983. Die Schwebstoffe der Traun und des Traunsees. Limnologische Untersuchung Traunsee-Traun, Amt O. Ö. Landesregierung Bericht Nr. 11: $50 \mathrm{pp}$.

Pechlaner, R. \& C. Sossau, 1982. Die Ergebnisse der fünfjährigen Studie 'Limnologische Untersuchung Traunsee-Traun', Amt O. Ö. Landesregierung Bericht Nr. 13: $234 \mathrm{pp}$.

Sturm, M. \& J. Müller, 1984. Die Untersuchung langer Sedimentprofile und die Verbreitung von Turbiditen im Traunsee. Limnologische Untersuchung Traunsee-Traun, Amt O. Ö. Landesregierung Bericht Nr. 12: 97-131.

Accepted 18 March 1986. 